\title{
University Social Responsibility Towards Sustainable Coexistence of Humans and Animals on Campus: Case Study on Bilgi Animal Friends Society
}

Preliminary communication _ DOI 10.22522/cmr20180130, received on 13 February 2018 UDK: 005.35:378.4 - $636.0 \overline{4} 5$

$\cdots \ldots \ldots$

Barika Goncu, PhD

Department of Public Relations, Istanbul Bilgi University, Turkey. Email: barika.goncu@bilgi.edu.tr

\section{Vehbi Gorgulu, PhD}

Department of Public Relations, Istanbul Bilgi University, Turkey.

Email: vehbi.gorgulu@bilgi.edu.tr (corresponding author)

\section{Abstract}

BILGI Animal Friends Society (BAFS) is a university social responsibility project of Istanbul Bilgi University, initiated to raise awareness about the stray cats and dogs living on campus. The aim is to enhance the institution's interaction with its social and physical environment and its stakeholders for the common good. Another aim is to improve the living standards of stray animals on campus by intensifying their interaction with humans, and by cooperating with the local municipality for their health and well-being. BAFS, the case of our research, is important for being one of the primary university-based corporate social responsibility initiatives in Turkey to raise awareness on stray animals, to improve their living conditions on campus, and to create an exemplary model of sustainable coexistence of humans and animals. In line with this, our research explores structural and operational characteristics of the BAFS initiative and assesses its relation with key principles of the university social responsibility approach.

Keywords: USR, Istanbul Bilgi University, environment, animal, social change. 


\section{Introduction}

CSR is a pattern of corporate self-regulation that aims to foster a corporation's reputation and legitimacy in the public eye through increasing the corporation's interaction with its social and physical environment (Sen, Bhattacharava, Korschun, 2006). Communicative and networked practices play an important role for CSR for spreading the corporation's intended message to larger groups of individuals. Driving organizational and social change requires the establishment of an effective CSR strategy that encourages internal and external publics of the corporations for participation. This requirement is also relevant for the universities, as we have observed an increase in debates over university social responsibility (USR), USR projects and strategies.

The boundaries of CSR and sustainability initiatives of various organizations are expanding to include issues relating to animals, whether in the framework of animal welfare or animal rights. This is due to several problems emerging out of old and new patterns of interaction between humans and animals: the impact of animal agriculture on greenhouse gas emissions (Food and Agriculture Organization of the UN, 2016) emerging discussions and innovative alternatives on "ethical eating” (Allied Market Research, 2016), initiatives by various countries and institutions (i.e. The Nonhuman Rights Project) to challenge forms of animal captivity such as zoos and circuses (Worland, 2017), and increased interest toward the treatment and handling of stray animals are some of the reasons why CSR for animal issues are rapidly entering the organizational radar.

According to the latest Animal Protection Index (2015) by World Animal Protection ${ }^{1}$, in which the animal welfare policies and legislation of 50 countries (including Turkey) are ranked based on 15 indicators, the overall ranking of Turkey is E, where the highest ranking is A and the lowest ranking is G. Furthermore, the Animal Rights Watch Center ${ }^{2}$ in Turkey has reported 8.216.506 cases of torture, 1.505 .404 .792 cases of imprisonment, and 42.711 .818 violations of

1 World Animal Protection (WAP) is a London based registered charity and a company with affiliated offices around the world. WAP has consultative status at the Council of Europe and collaborates with national governments, the UN, the Food and Agriculture Organization, and the World Organization for Animal Health. For details see https://www.worldanimalprotection.org/world-animal-protection-governance.

2 Hayvan Hakları İzleme Merkezi (Animal Rights Watch Center) is an NGO initiative which collects, archives, observes and reports animal rights infringements in Turkey. The initiative receives support from Sivil Düşün EU Programme. For details see http://sivildusun.net/english/. 
physical integrity against animals in Turkey in 2016. On the other hand, there is the presence of a major federation (HAYTAP) and a confederation (HAYKONFED) that represent more than 200 local or national NGOs; a collective representing animal rights groups and clubs of 25 universities (UNIHAK); and hundreds of individuals volunteering for the protection of animals, provides grounds for positive future potential for the animals in Turkey. Although the term "animal” represents all non-human animals, likewise in other parts of the world, the animal welfare and animal rights initiatives in Turkey focus mainly on the cats and dogs living on their own in rural areas and in urban centres, some of which are abandoned pets.

Historically, dogs and cats living in the streets have been an integral part and a distinguishing character of Turkish life. Turkish people have a tradition of feeding and taking care of these stray animals (Alkan, 2016). This tradition of protecting animals dates back to the Ottoman Empire, when the Ottoman Sultans built special houses for birds and enacted special decrees for the welfare of working animals (Gürler, Osmanağaoğlu). However, especially the street dogs, have been subjected to several deportations and annihilations initiated by both the rulers of the Ottoman Empire and the governments of the Turkish Republic, as a consequence of "Western modernization" (Alkan, 2016). Cats were luckier, as they are considered ritually clean animals in Islam, and were blessed by the Prophet Muhammad.

Currently, animals in Turkey are protected by the Act on Animal Protection, passed in 2004. Under this act, it is strictly forbidden to kill animals living in the streets, and it is a municipal duty that the street dogs are vaccinated, neutered and spayed, and brought back to where they were picked up from. Municipalities are also responsible for establishing clinics and temporary shelters for street animals. However, the often insufficient public budgets, the low level of education as regards living with animals, and massive construction projects continuously limiting the spaces of animals lead to the deportation of street dogs to the uninhabited areas and the forests at the edges of the cities (Alkan, 2016; Gürler, Osmanağaoğlu, 2009). In this framework, animal rights NGOs and individual volunteers are in constant negotiation with and struggle against both the municipalities and different organizations such as companies, educational institutions and housing developments, in order to keep street animals in their original neighbourhoods. In such a context, the attitude of various organizations towards animals has become a litmus test for empathy and social responsibility. While organizations which take care and provide space for street animals are celebrated; those which are not 
empathic and deport them are severely criticized, especially through the multiplier effect created by NGOs and volunteers in social media.

BILGI Animal Friends Society (BAFS) is a university social responsibility (USR) project of Istanbul Bilgi University (IBU) that aims to enhance the university's interaction with its social and physical environment and its stakeholders for the common good. BAFS was initiated in 2015 by academic and administrative staff, as well as the students of IBU, in order to raise awareness about the stray cats and dogs living on campus. Another aim was to improve the living standards of stray animals on campus by intensifying their interaction with humans, and by cooperating with the local municipality for their health and well-being. BAFS, which is the case of our research, is important for being one of the primary USR initiatives in Turkey to raise awareness on stray animals, to improve their living conditions on campus, and to create an exemplary model of sustainable coexistence of humans and animals.

Our study aims to shed light on the theoretical and practical implications of increasing humananimal interaction through a university-based CSR initiative on the campus environment. The findings of the study reveal daily structural characteristics, communication patterns, working routine, ethics, financial opportunities and limitations of the BAFS project. It also questions whether the initiative has succeeded in transforming the living conditions of stray animals living on campus by raising awareness. Findings inform other universities as well as corporations in general, in terms of applicability of an animal-focused USR projects in a bordered public sphere.

\section{Literature Review}

\subsection{Why CSR Matters}

In recent years, CSR has attracted significant attention among both corporate professionals and scholars (Shim, Yang, 2016). CSR remains as one of the key practices for today's corporations since it has moral, ethical and social implications that foster mutually beneficial relationship between corporations and their stakeholders (Aksak, Duman, 2015; Bruning, Ledingham, 2000; Cutlip, Center, Broom, 2000; Ki, Hon, 2007; Ledingham, 2006). Lai, Chiu, Yang and Pai (2010) define CSR as “activities taken by corporations to enhance economic, social and 
environmental performance voluntarily” (p. 458). In another definition, Pride and Ferrell (2006) explain CSR as corporate citizenship in which a company enables pro-active social acts to enhance community development and welfare.

From a relatively utilitarian point of view, Jenkins (2009) argues CSR should be viewed in terms of how entrepreneurs manage their business to ensure an overall positive impact among the society. Such a view falls short in terms of understanding and assessing stakeholder expectations, which have been one of the primary concerns of scholars and practitioners with expertise on CSR. From the very early days of CSR studies, scholars such as Bowen (1953) and Carroll (1979) underlined the sense of responsibility that managers should feel towards their stakeholders. In line, Bowen (1952) argued that especially large companies were perceived as power centres whose activities and decisions could potentially impact on everyday lives of individuals. Similarly, Carroll (1979) claimed that the CSR practice of especially large companies should encompass economic, legal, ethical and voluntary expectations of stakeholders. In this study, CSR is treated as a pro-active practice that is rooted in the sense of responsibility towards relevant stakeholders. Therefore, the definition of Pride and Ferrell (2006) provides a more social and holistic approach towards CSR, and practices such as university social responsibility that are highly related with the phenomenon.

In a business era marked by complex interactions among various stakeholders, corporations need to establish strong and long-term CSR agendas that derive from company visions and address the needs and demands of the relevant publics. CSR projects enacted by companies should match with the expectations of the related publics. Moreover, trade-offs should be made between competing interests of stakeholders to increase efficiency and impact when needed. When enacted efficiently, CSR has the potential to increase stakeholder engagement, and even purchase intention among customers, especially on social media. For instance, the study of Uzunoğlu, Türkel and Akyar (2017) reveals that CSR related Twitter messages on products create higher influence over customer purchase intention than purely promotional messages. Additionally, CSR has the potential to increase a company's reputation, especially when the company already has a good reputation with no crisis (Shim, Yang, 2016). In that sense, CSR is not only important for companies to strengthen their ties with their stakeholders, but also to enhance their reputation, public image and share in relevant markets. 
CSR has also become important for educational institutions such as the universities. Many reputable universities in the United States such as New York University has started to integrate CSR related courses to their curriculums (NYU, 2017), while others such as Stanford University established fellowship programs to encourage fellows to work full time with a mentor in CSR department of a relevant corporate headquarters or foundation (Stanford University, 2017). Some in Europe such as University Politehnica of Bucharest started their own USR initiatives by enacting international projects. One of their projects is focusing on building the Europe and Development of a Community Reference Framework (EU-USR), which aims to encourage larger amounts of social responsibility practices in European universities (EUUSR, 2017). Therefore, it can be said that USR practices have recently emerged as a subfield of social responsibility practices that are enacted by educational institutions, and mainly the universities, to strengthen ties with relevant publics.

\subsubsection{Components of USR \&S}

USR has drawn considerable scholarly attention in terms of building USR frameworks and determining relevant USR components (e.g. Ahmad, 2012; AUN, 2012; Mohamed, 2015; Tetřevová, 2010). For instance, Tetřevová (2010) suggests, USR should be considered as a combination of practices at different levels. These levels include economic, ethical, social, philanthropic and environmental levels (Tetřevová, 2010). More specifically, The Association of Southeast Asian Nations (ASEAN) University Network (AUN, 2012) proposed an alternative conceptual framework (USR and Sustainability framework), which include the following components:

(1) Teaching and learning, research and academic services,

(2) University's governance and administration,

(3) Community involvement,

(4) Campus life.

These components aim to encourage the USR \&S practice at different levels of the university life, while generating solutions for the social, economic and environmental challenges (Chen, Nasongkhla, Donaldson, 2015). 
The first component, "teaching and learning, research and academic services" is mainly about the university's common mission. The component explores how a university's academic expertise is applied for generating solutions for social causes. The second component, "university's governance and administration" is related with university's organizational and managerial approaches towards social issues. The third component, "community involvement" explores how the community is encouraged to engage in USR \& S activities for the creation of a better social environment. Lastly, the fourth dimension is related with the experiences of students and university staff during their time inside the campus. On-campus experiences are essential to test the current USR \& S strategy, to ensure that the implemented USR \& S activities work out effectively and can be extended beyond the borders of the campus (AUN, 2012). The framework remains characteristic in terms of considering the sustainability dimension along with the USR as an essential component. The traces of this approach can be observed in the study of Mohamad (2015), who explains that applying the USR \& S framework is important to understand the link between various internal and external stakeholders over a particular social issue.

In the current study, we apply the USR\&S framework developed by AUN (2012), since the framework is applicable for an exploration on the dynamics of the BAFS. BAFS is related with the university's mission and services, academic staff and administration, relations with the community and life on campus. Moreover, the BAFS project aims to create an environment that ensures the sustainable coexistence of humans and animals on campus. In that sense, the USR \& S framework of AUN (2012) remains relevant in terms of exploring and understanding the dynamics of the BAFS initiative. However, before that it is important to understand the contextual background of stray animals in Turkey, which is a country-specific case that lays the basis for the emergence and operation of the BAFS initiative.

\section{Methodology}

As Baxter and Jack (2008) argue, qualitative case study approach is a useful method to explore organizational context of initiatives (p. 544). Yin (2003) asserts that qualitative case study method is especially efficient when the contextual conditions are relevant to the phenomenon focused. Moreover, the qualitative case study method allows the researcher to raise "why?" 
and "how?" questions by analysing the phenomenon with relevant resources and within the relevant contextual conditions. Prepared in line with the primary aims of the study, the research questions of our study are as follows:

Q1: What are the structural and operational characteristics of the BAFS initiative?

Q2: How can the BAFS initiative be associated with the key principles of USR?

The primary data collection technique of our research is guided semi-structured in-depth interview. Patton (1987) explains, in-depth interview offers the researcher the opportunity “to achieve a holistic understanding of the interviewee's point of view or situation” (p. 113). Moreover, guided semi-structured interviews allow researchers to elicit information on specific topics, on which they aim to obtain data. During the process, researcher begins with a set of open-ended questions and probes the interviewee to provide details and clarifications through their response. Thus, a semi-structured questionnaire and a basic checklist are designed prior to the interview date for guidance.

Interviewees are selected via snowball sampling technique, which is widely used in qualitative research. As Biernacki and Waldorf (1981) explain, “the method yields a study sample through referrals made among people who share or know of others who possess some characteristics that are of research interest” (p. 141). The first interview was conducted with an academic staff, who referred us to one of his colleagues that volunteers for the BAFS initiative. The second potential interviewee received an email request for participation in the research process. The request e-mail also included information about primary aims of the research. Upon acceptance, a meeting time and date were set with the interviewer. At the end of the interview, researchers consulted with the interviewer for the third participant. The same process followed throughout each interview.

In total, nine in-depth interviews were conducted with BAFS members between 15 March and 15 May, 2017, in a meeting room at Istanbul Bilgi University, central campus, located in Eyüpsultan district of İstanbul, Turkey. The final sample included equal number of individuals that represent different components of USR \& S: 3 representatives from academic staff, 3 representatives from volunteer students and 3 representatives from operational staff from IBU. An additional interview was conducted with the external corporate communications consultant of Istanbul Bilgi University, in order to evaluate the dimensions of the BAFS 
initiative from the perspective of a communications professional. The external corporate communications consultant of the university is not directly involved in the project. Therefore, she was able to embrace a more objective approach towards the initiative while answering the interview questions.

Interview questions mainly focused on structural characteristics of BAFS initiative. The questions directed to academic staff, volunteer students and operational staff aimed to explore interviewees' motivation to participate and their roles in the initiative. Questions prepared for the interview with external corporate communication consultant of the university mainly focused on BAFS' image in the public and professional eye. Each interview lasted approximately 45 minutes.

In the manuscript, the academic staff interviewees are coded and will be referred as A1, A2 and A3. The volunteer students are coded and will be referred as S1, S2 and S3. The operational staff are coded and will be referred as $\mathrm{O} 1, \mathrm{O} 2$ and $\mathrm{O} 3$. The external corporate communications consultant of Istanbul Bilgi University is coded as C1 and referred as C1 throughout the manuscript. The primary and secondary sources, such as initiative's catalogues, exhibition materials and collaborations with various in-house and external stakeholders also inform our analysis.

\section{Findings}

\subsection{Istanbul Bilgi University and USR \&S}

Istanbul Bilgi University (IBU) was established in 1996 in İstanbul, Turkey, by embracing the principle "Non scholae, sed vitae discimus" (We do not learn for the school, but for life). The university was established by a group of young entrepreneurs and academics as a private, nonprofit institution (Atakan, Eker, 2007). The university established a long term partnership with Laureate Education in order to expand its international network. Since then, it has been the only member of Laureate Education network from Turkey (IBU official website, 2017).

The university, which has four main campuses in various central districts of İstanbul, approximately 25,000 students, 1,000 teaching staff members, 7 faculties, 5 institutes, 4 schools, 
3 vocational schools, and 200 programs that offer education to its associate, undergraduate and graduate students (IBU official website, 2017). Social responsibility is one of the main concerns of IBU, which is also stated among its missions, aside with "respect for universal rights and freedoms", "academic freedom and responsibility" and "respect in pluralism and diversity":

“İstanbul Bilgi University undertakes to contribute to science, artistic production, and the development of technology; to educate individuals whose research and problem solving skills have developed in an atmosphere of free thought and an awareness of social responsibility, whose competencies meet international standards, and who, in addition to respecting the rules of ethics and of professional objectivity, are also open to multidisciplinary approaches; and to serve society within multi-dimensional standards of quality” (IBU official website, 2017).

This statement underlines the fact that social responsibility is integrated within the education philosophy of IBU, which is characterized by its emphasis on "learning for life". This emphasis can be perceived as one of the main reasons why the university refers to its students as "individuals" in its missions, in order to underline the fact that the education offered by IBU surpasses the borders of the school and encourages lifelong learning. IBU's approach towards social responsibility can be claimed to be towards its stakeholders in general, and, thus, is not limited the borders of the university campuses.

At the educational level, the CSR and social responsibility have been integrated into the curriculums of many undergraduate and graduate programs offered by IBU, such as Business Administration, Human Resources Management, Public Relations, Cultural Management, European Union Studies, Social Projects and Management of Non-Governmental Organizations, Marketing, Health Management, Ergotherapy, Nursing, Physiotherapy, and Rehabilitation and General Education courses (IBU official website, 2017). In that sense, the university aims to extend its missions on social responsibility through offering courses to its students at various academic levels.

IBU also hosts a Centre for Civil Society Studies, which is an autonomous institution that serves as an umbrella unit for projects such as Youth Studies Unit, Children Studies Unit and Social Incubation Centre. Youth Studies and Children Studies units encourage scientific research 
on government policies related with youth and children, while the Social Incubation Center serves as a hosting space for various training programs on social issues, mainly enacted by civil society organizations. Research for the Environment, Energy and Sustainability is another initiative of the university, which aims to contribute to the solution of environmental problems and sustainable production and consumption of energy sources. Other university initiatives include EU Institute, Human Rights Law Research Centre, Centre for Migration Research and Centre for Sociology and Education Studies. Overall, all of these initiatives are curated in line with the United Nations Global Compact (UNGC), which is "both a policy platform and a practical framework for companies that are committed to sustainability and responsible business practices” (ungc.bilgi.edu.tr, 2017). UNGC aims to align business operations and strategies over ten universally accepted principles centred around human rights, labour, environment and anti-corruption, to encourage actions in line with the goals of the United Nations (UN) (ungc.bilgi.edu.tr, 2017). Thus, mentioned initiatives enacted by IBU, aim to raise awareness on specific social issues and suggest potential solutions, in accordance with the principles of the UNGC. The university management also publishes detailed progress reports on activities and projects curated by these initiatives (e.g. Anonymous, 2016).

\subsection{BILLGI Animal Friends Society as a University Social Responsibility Project}

\subsubsection{Structural Characteristics of BİLGI Animal Friends Society}

BAFS was initiated in 2015 by academic and administrative staff, as well as the students of IBU. BAFS, which first started as a senior project of the IBU Public Relations Program Student Agency PUBLICA İletişim, was launched with a photograph exhibition on campus in May 2015. The aim of the exhibition was to raise awareness on stray animals and introduce campus animals to the population of the university.

The premiere of the exhibition hosted various stakeholders such as university management, academicians, students and Eyüpsultan municipality representatives, where the IBU campus is located. Later on, the exhibition was documented with a short movie (Bilgi Hayvan Dostları Fotoğraf Sergisi, 2015) and the exhibition material was transferred into a digital platform (bilgihayvandostlari.com, 2017). The digital platform also includes information 
on the initiative's on-campus and off-campus activities and a form to encourage volunteer contribution (bilgihayvandostlari.com, 2017).

In 2016, the BAFS initiative was transformed into a USR project supported by the university management. A1 explains that the demands of the volunteer students and academicians have enabled this transformation:

“The demands varied from responding to the needs of the animals living on campus to providing solutions to the problems related with the existence of these animals. We also prioritize the demands of the municipality where our campus is located, as municipalities are one of the primary stakeholders of projects such as BAFS, marked by animal-human interaction." (In-depth interview with A1, 2017)

On the other hand, A2 explains that the process has not been easy. Although the initiative was officially established in 2015, its roots could be traced in the mid-2000s, when a group of IBU academicians voluntarily started to support stray animals on campus. During that time, the initiative encountered various challenges:

"The former belief was that stray animals had to be replaced to an area where they could remain distant from campus, where the human population was dense. As a small group of academicians, we volunteered to change this perception with the motto, 'Respect for the animals' right to exist'. Our initiative was later supported by a large group of volunteer students. And now, BAFS remains as one of the most important USR projects of IBU, which is also strongly supported by the university management.” (In-depth interview with A2, 2017)

The routine undertakings of the BAFS initiative include regular feeding and care of campus dogs and cats, daily play and exercises for dogs, spaying and neutering of campus animals, special events for adoption, and providing outdoor shelters especially for winter time. BAFS also undertakes projects such as animal first aid workshops, and free therapy sessions for students and staff with anxiety towards animals. BAFS is currently the main platform of communication and action for all campus animals and their problems, with administrative and financial support from the top management of the University. As S1 states:

"We as BAFS volunteers, consider ourselves quite lucky, due to the support of the University management. The management has signed a long-term contract with a 
veterinarian and pays for all medical needs of our campus animals. In the same manner, the management also provides support in terms of special events and workshops." (Indepth interview, 2017)

\subsubsection{Participant Profile of BİLGİ Animal Friends Society}

Following its official establishment, BAFS attracted considerable attention. Volunteers range from operational staff, to academicians and students. A student volunteer explains, "I was a member of a student club called 'Barınakta Hayat Var' (There is life in the shelter) but I had no idea about BAFS initiative until a professor asked if I could transfer a stray cat to the vet. I was happy to hear that such an initiative existed on campus so I quickly became a member." (In-depth interview with S1, 2017) He adds, in order to do volunteer work, one has to know that he will take pleasure from that experience:

"All volunteer members of our initiative are animal lovers. They do not see their duties as extra work. Food bowls on campus are always full. Animals with disabilities are being taken care of always on time." (In-depth interview with S1, 2017)

S2 and S3 explain they heard about the initiative during a course offered within the university curriculum: "I learnt about the initiative while taking the Human-Animal Interaction course. I was already caring about stray animals by finding them new homes. It was good to know that other people on campus also cared about them, so I joined the team." (In-depth interview with S2, 2017) Similarly, S3 adds: "I used to help stray animals individually because I thought all initiatives working on animal rights remained problematic due to power struggles. I was happy to see individuals like me at BAFS initiative and this is why I became a member." (Indepth interview with S3, 2017)

As can be inferred from the accounts of volunteer students, members of the initiative were already interested in supporting the rights of stray animals, before joining the BAFS initiative. The situation is similar with the operational staff: "I was already feeding stray cats and dogs on campus before joining the BAFS initiative. I knew that there were many students and professors, who were taking care of stray animals just like me. I joined the initiative, as professors informed me about their on-going works related with enhancing living standards of stray animals on campus." (In-depth interview with 01, 2017) Similarly, O2 states that he was a former volunteer for feeding stray animals on campus, especially the cats: 
"I first heard about BAFS when I was invited to their exhibition. The exhibition included photos of stray cats and dogs living on campus (...) Me and a group of colleagues were already raising money to buy pet food for stray animals. As we met professors and students, who were also interested in taking care of stray animals during the exhibition, we decided to join the BAFS initiative.” (In-depth interview with O2, 2017)

Drawing from the accounts of operational staff interviewed, it can be inferred that BAFS is structured as an inclusive initiative, which is not only limited with the academic side of the university. The initiative also embraces the guidance of the university management, as well as the participation and contribution of the operational staff, who ensure the efficiency of the daily operations on campus; from technological assistance to security. Such diverse participant profile and the efficient volunteer operation of the initiative make it one of the most inclusive USR projects enacted and supported by the university.

\subsubsection{Opportunities and Limitations of BİLGI Animal Friends Society}

The structural characteristics and participant profile of the BAFS point out to the initiative's certain structural opportunities and limitations. First of all, the BAFS initiative stands out as an exemplary USR project especially for countries like Turkey, where stray animals are large in quantity. In such countries and environments, where stray animal population is intense, it is important to foster the recognition of these stray among all relevant stakeholders, in order to create an animal-friendly environment, where healthy human-animal interactions are sustained. As can be inferred from the BAFS example, such practices can be based on voluntary practices. As our interviewees reveal, there are many individuals caring for enhancing the living standards of stray animals, without the supporting mechanism of an organization. However, the spirit of collectivism enhances the satisfaction drawn from helping stray animals, as it allows individuals to share their experiences and receive help from each other in times of need. It also allows such groups an official status when interacting with relevant stakeholders such as the university management and the municipality representatives. 
Table 1. Structural opportunities and limitations of the BAFS initiative

\section{Opportunities}

Recognition of stray animals on campus

Increase in human-animal interaction

Satisfaction drawn from voluntarism

Support system of the university management

\section{Limitations}

Prejudices and hate towards stray animals Recognition of stray animals' right to exist Insufficient number of student volunteers

Lack of a crisis communication team

Besides opportunities, interviews conducted with members of the BAFS initiative point out to various limitations. One of the most outstanding limitations is related with individuals' prejudice and even hate towards stray animals. This is especially the case with some individuals, such as students, who ask for an animal-free environment as they are afraid of animals in general. This situation points out to the need to communicate stray animals' right to exist towards larger groups of stakeholders. Mainly composed of members who have already displayed interest in the care of stray animals, the initiative needs to spread their culture towards larger groups of individuals on campus to overcome prejudice and hate against stray animals.

Another limitation, which is the insufficient number of student volunteers, can also be related with this situation, for not having efficient number of supporters to communicate the caring culture of the initiative to larger groups of individuals on campus. Furthermore, the initiative needs a crisis communication team in order to negotiate clashing interests of various stakeholders in times of unexpected conflicts related with the existence or needs of stray animals living on campus.

\subsubsection{Recognition of BİLGí Animal Friends Society}

BAFS initiative is not only important for improving the living standards of stray animals on campus, but also for having the potential to enhance IBU's reputation and recognition in its industry as an animal friendly university. As Heionen's (2011) research points out, many individuals spend hours on online social networks such as Facebook and YouTube in order to watch funny animal videos. Moreover, individuals express their love and support for animals in general, by supporting their rights through petition campaigns (e.g. change.org, 2017). Some even boycott restaurants and shops for treating animals in a bad manner or not being animal friendly. 
Thus, in the age of social media, it is more important for institutions to care about rights of animals. Even a small crisis that results with the violation of animal's right to live can cost a company millions of dollars. Although an institution does not have to invest directly for the enhancement of animals' living standards, it has to respect and remain sensitive for their existence in order to abstain from potential crisis situations.

In terms of recognition, BAFS can be perceived as an important step for IBU. Already a highly respectable university with more than 30.000 graduates, IBU has strengthened its institutional image by drawing attention to the challenges experienced by stray animals in complex living environments and providing solutions for their healthy existence. At this point, C1 explains: "Individuals caring about rights of animals are large in numbers. Thus, the recognition of the BAFS initiative at a wider scale will inevitably strengthen its contribution to the field. It is also well known that animal-friendly spaces leave better impression in the eyes of individuals.” (In-depth interview with C1, 2017)

A3 additionally explains that the initiative is important for IBU since it is one of the projects that directly match with the university's vision and missions:

"IBU has always been in touch with the neighbourhoods where its campuses are located. The university has enacted various community service programs in order to enhance their social standards. I believe BAFS is also a project that serves for its neighbourhood and its communities. It has the potential to contribute to the university's image in the eyes of its publics.” (In-depth interview with A3, 2017)

The official status of BAFS has already provided the initiative recognition among its stakeholders. As a result, the initiative transferred some of their operations to off-campus activities and actions. One of these actions has been building a relationship with the Eyüpsultan Municipality's Veterinary Office in 2014, to receive support when a stray animal is injured and in need of health care. As a result of this relationship, BAFS initiative was invited to a workshop in 2014 organized with the participation of Eyüpsultan Municipality representatives, representatives from NGOs supporting rights of animals, local authorities and residents. Accordingly, the initiative started organizing activities to feed and respond to the needs of animals living in the shelter of the Eyüpsultan Municipality and strengthened their bonds with especially the external stakeholders. 


\section{Concluding Remarks}

Stray animals have always been an essential component of daily street life in Turkey. The government strategy in taking care of stray animals is collecting them from the streets, vaccinating them and treating them if they have any health issues that would be concerning for the public health and releasing them back to the streets. Thus, free-roaming cats and dogs have become a part of daily street culture of Turkey, as individuals can interact with these animals whether in a restaurant or at the entrance of a movie theatre.

As a result of this intense interaction, many business managers are taking the mission to take care of the stray animals that roam around their business locations. The main strategy of especially the restaurant managers to take care of stray animals has been collaborating with animal rights NGOS and collecting the leftover food from consumers' plates to feed stray animals (ajanimo.com, 2016; patiliyo.com, 2016; petoskop.com, 2016).

Such interest in taking care of stray animals is not only important for their survival, but also to improve their psychological conditions. Stray animals live in very dangerous conditions especially in metropolitan areas, where they have to deal with various life-threatening situations. Cetingulec (2016) explains that especially abandoned stray dogs have the tendency to commit suicides by starving to death for being left alone at the streets by their previous owners. These challenges experienced by stray animals have not only encouraged animal rights activists to take further missions, but also environmentally sensitive companies and individuals to take action.

BAFS can be perceived as such an initiative, established with the support of animal lover students, professors and operational staff in a university environment to enhance the living standards of stray animals. As a successfully operated USR project based on volunteer effort with administrative and financial support from the University management, BAFS points out to the fact that taking care of stray animals is an essential component of increasing human-animal interaction and fostering a sustainable living environment for all living creatures. In that sense, BAFS can be considered an exemplary practice for universities which are located in countries or neighbourhoods where the stray animal population is dense. In such environments, solutions need to be developed to integrate these animals into the social environment they belong to and humans hold the key to these animals' rightful existence. 


\section{Reference List}

- Ahmad, J. (2012). Can a university act as a corporate social responsibility (CSR) driver? An analysis. Social Responsibility Journal, 8 (1), 77-86.

- Aksak, E. O., Duman, S. A. (2015). The online presence of Turkish banks: Communicating the softer side of corporate identity. Public Relations Review, 41, 119-128.

- Alkan, A. (2016). Deportation as an urban stray dogs management policy: Forest dogs of Istanbul. Lex Localis - Journal of Local Self-Government, 14 (3), 615-638.

- Atakan, M. G. S., Eker, T. (2007). Corporate identity of a socially responsible university - A case from the Turkish higher education sector. Journal of Business Ethics, 76, 55-68.

- Baxter, P., Jack, S. (2008). Qualitative case study methodology: Study design and implementations for novice resarchers. The Qualitative Report, 13 (4), 554-559.

- Biernacki, P., Waldorf, D. (1981). Snowball sampling: Problems and techniques of chain referral sampling. Sociological Methods \& Research, 10 (2), 141-163.

- Bonnett, M. (1999). Education for sustainable development: A coherent philosophy for environmental education? Cambridge Journal of Education, 29 (3), 12-17.

- Bowen, H. R. (1953). Social responsibilities of the businessman. New York: Harper.

- Bruning, S. D., Ledingham, J. A. (2000). Perceptions of relationships and evaluations of satisfaction: An exploration of interaction. Public Relations Review, 26, 85-95.

- Carroll, A. B. (1979) Three-dimensional conceptual model of corporate performance. Academy of Management Review, 4, 497-505.

- Chen, S., Nasongkhla, J., Donaldson, J. A. (2015). University social responsibility: Identifying an ethical foundation within higher education institutions, TOJET: Turkish Online Journal of Educational Technology, 14 (4), 165-172.

- Chiras, D. (1998). Environmental science: A systems approach to sustainable development. New York: Wadsworth Publishing.

- Cutlip, S. M., Center, A. H., Broom, G. M. (2000). Effective public relations (8th Ed.). Englewood Cliffs, New Jersey: PrenticeHall International, Inc.

- Davis, S. A., Edmister, T. H., Sullivan, K., West, C. K. (2003). Educating sustainable societies for the twenty-first century. International Journal of Sustainability in Higher Education, 4 (2), 169-179.

- Dominguez Pachon, M. J. (2009). Responsabilidad social universitaria. Humanismo y Trabajo Social, 8, 37-67.

- Giuffré, L., Ratto, S. E. (2014). A new paradigm in higher education: University social responsibility. Journal of Education \& Human Development, 3 (1), 231-238.

- Gürler, A. M., Osmanağaoğlu, Ş. (2009). Türkiye’de hayvanları koruma kanununun tarihsel gelişimi. Kafkas Üniversitesi Veterinerlik Fakültesi Dergisi, 15 (3), 325-330.

- Heionen, K. (2011). Consumer activity in social media: Managerial approaches to consumers' social media behavior. Journal of Consumer Behavior, 10 (6), 356-364.

- Jenkins, H. (2009). A business champions for corporate social responsibility. Journal of General Management, 18 (1), 21-36.

- Ki, E. J., Hon, L. C. (2007). Testing the linkages among the organization-public relationship and attitude and behavioral intentions. Journal of Public Relations Research, 19, 1-23.

- Lai, C.-S. Chiu, C.-J., Yang C.-F., Pai, D.-C. (2010). The Effects of Corporate Social Responsibility on Brand Performance: The Mediating Effect of Industrial Brand Equity and Corporate Reputation. Journal of Business Ethics, 95 (3), 457-469.

- Leal Filho, W. (1999). Sustainability and university life. New York: Peter Lang.

- Ledingham, J. A. (2006). Relationship management: A general theory of public relations. In: C. H. Botan, V. Hazleton (Eds.), Public relations theory II (pp. 465-483). Mahwah, NJ: Lawrence Erlbaum Associates.

- Mat, S., Sopian, K., Mokhtar, M., Ali, B., Hashim, H.S., Rashid, A. K. A., Zain, M. F. M., Abdullah, N. G. (2009). Managing sustainable campus in Malaysia: Organizational approach and measures. European Journal of Social Sciences, 8 (2), 201-214.

- Mohamed, A. T.E.(2015). A framework for university social responsibility and sustainability: The case of South Valley University, Egypt. International Journal of Social, Behavioral, Educational, Economic, Business and Industrial Engineering, 9 (7), 2407-2416. 
- Orr, D. (1994). Earth in mind: On education environment, and the human prospect. Washington, D.C.: Island Press.

- Patton, M. Q. (1987). How to use qualitative methods in evaluation. California: Sage Publications, Inc.

- Pride, W. M., Ferrell, O. C. (2006). Marketing: concepts and strategies. Boston, MA: Houghton Mifflin.

- Reiser, J. (2007). Managing university social responsibility (USR): International sustainable campus network: Best practices future challenges, April 25-27, Zurich, Switzerland.

- Sen, S., Bhattacharya, C. B., Korschun, D. (2006). The role of corporate social responsibility in strengthening multiple stakeholder relationships: A field experiment. Journal of the Academy of Marketing Science, 34 (2), 158-166.

- Shim, K., Yang, S. (2016). The effects of bad reputation: The occurrence of crisis social responsibility, and perceptions of hypocrisy and attitudes toward a company. Public Relations Review, 42, 68-78.

- Tetřevová, L. (2010). Alternative forms of university: Private partnership. Economics and management, 15, 807-813.

- Schneller, C., Thöni, E. (2011). Universities and their social responsibilities. Asia Europe Foundation.

- Uzunoğlu, E., Türkel, S., Yaman Akyar, B. (2017). Engaging consumers through corporate social responsibility messages on social media: An experimental study. Public Relations Review, 43 (5), 989-997. http://dx.doi.org/10.1016/j.pubrev.2017.03.013.

- Wigmore-Álvarez, A., Ruiz-Lozano, M. (2012). University social responsibility (USR) in the global context: An overview of literature. Business \& Professional Ethics Journal, 31 (3), 475-498.

- Vallaeys, F., De La Cruz, C., Sasia, P. M. (2009). Responsabilidad Social Universitaria. Manual de Primeros Pasos. Mexico D.F.: McGraw-Hill.

- Yin, R. (2003). Case study research: Design and methods. California: Sage Publications, Inc.

\section{Internet Sources}

- Ajanimo.com (2016). Taps Bebek’ten sokak hayvanları için Bi Kutu Dostluk paketi, Ajanimo. Retrieved from http://www. ajanimo.com/taps-bebekten-sokak-hayvanlari-icin-bikutu dostluk-paketi/?nonamp=1. 26 June 2018.

- Allied Market Research (2016). World meat substitute market - opportunities and forecasts 2014-2020. Retrieved from https:// www.alliedmarketresearch.com/meat-substitutemarket. 26 June 2018.

- Animal Protection Index (2015). World Animal Protection. Retrieved from http://api.worldanimalprotection.org/about. 26 June 2018.

- Anonymous.com (2016). BíLGİ'de sosyal sorumluluk. Retrieved from http://www.bilgi.edu.tr/site_media/uploads/files/2016/05/09/ bilgide_sosyal_sorumluluk-rosur.pdf. 26 June 2018.

- AUN (2012). AUN USR \& S: University social responsibility and sustainability. Retrieved from http://www.aunsec.org/pdf/ aunwebsite/usrsppocketbook.pdf. 26 June 2018.

- Bilgi Hayvan Dostları official website (2017). Retrieved from https://bilgihayvandostlari.com/. 26 June 2018.

- Bilgi Hayvan Dostları Fotoğraf Sergisi (2015). Retrieved from https://www.youtube.com/watch?v=P8U13Ci0JmI. 26 June 2018.

- Bilgi UNGC (2017). The global compact. Retrieved from https://ungc.bilgi.edu.tr/en/ungc.html. 26 June 2018.

- Cetingulec, T. (21 March 2016). Why are Turkey's abandoned dogs committing suicide? Al Monitor. Retrieved from http:// www.al-monitor.com/pulse/originals/2016/03/turkey why-dogs-commit-suicide.html. 26 June 2018.

- Change.org. (2017). Petitions related with animal rights. Retrieved from https://www.change.org/topics/animals\#mostrecent. 26 June 2018.

- Chase, G. (1998). Faculty development for environmental sustainability in higher education. Retrieved from http://www. escholarship.org/uc/item/0sb0f730?display=all. 26 June 2018.

- EU-USR (2017). EU-USR project. Retrieved from http://www.eu-usr.eu/. 26 June 2018.

- Food and Agriculture Organization of the United Nations (2016). The state of food and agriculture: Climate change, agriculture and food security. Retrieved from http://www.fao.org/3/a-i6132e.pdf. 26 June 2018.

- Istanbul Bilgi University (IBU) official website (2017). Retrieved from http://www.bilgi.edu.tr. 26 June 2018.

- HAKIM (2017). Hayvan hakları ihlalleri raporu. Retrieved from http://hayvanhaklari-izleme.org/duyuru/basin-toplantisi2016-hayvan-haklari-ihlalleri-rporunu-acikladik/. 26 June 2018. 
- HAYKONFED (2015). Confederation for animals' rights to live. Retrieved from http://www.haykonfed.org/2015/05/06/bizkimiz/. 26 June 2018.

- HAYTAP (2017). Federation for animal rights. Retrieved from http://ftp.haytap.org/index.php/200810231497/site-yardimcisayfalar/biz-kimiz. 26 June 2018.

- Nonhuman Rights Project (2017). Retrieved from https://www.nonhumanrights.org/. 26 June 2018.

- NYU (2017). Course details: Introduction to corporate social responsibility. Retrieved from https://www.sps.nyu.edu/professionalpathways/courses/MEEM1-CE9710-introduction-to-corporate-social-responsibility.html. 26 June 2018.

- Patiliyo.com. (2016). Güzel şeyler de oluyor: Kırçiçeği Restoran'dan sokak hayvanları için örnek proje (Good things happen: An exemplary project on stray animals from Kirçiçeği Restaurant). Retrieved from http://www.patiliyo.com/kircicegi-restoranhaytap/. 26 June 2018.

- Petoskop.com (2016). Ot Cafe sokaktaki hayvanları besliyor. Retrieved from http://www.petoskop.com/ot-cafe-musterilerihabersizce-sokaktaki-hayvanlari-besliyor/. 26 June 2018.

- Stanford University (2017). Corporate social responsibility fellowship. Retrieved from https:/haas.stanford.edu/students/ cardinal-quarter/fellowships/corporate-social-responsibility-fellowship. 26 June 2018.

- Unesco (1990). The Talloires declaration. Retrieved from http://en.unesco.org/themes/education-sustainable-development. 26 June 2018.

- UNIHAK - Animal Protection Group of Universities (2017). Retrieved from https://www.facebook.com/unihak/. 26 June 2018.

- Worland, J. (16 February 2017). The future of zoos: Challenges force zoos to change in big ways. Time. Retrieved from http:// time.com/4672990/the-future-of-zoos/. 26 June 2018. 


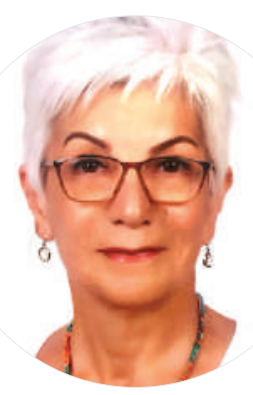

Bârika Göncü

Barika Göncü, PhD, established her own public relations consultancy business, acting as the Agency President between 1997 and 2011. Since 2011, she is a full-time lecturer at undergraduate Public Relations Program and graduate Public Relations and Corporate Communications Program of Istanbul Bilgi University. She also previously lectured as a parttime instructor at Istanbul Bilgi University between 1999 and 2011. She is currently a member of IDA's Board of Inspection and of the Media and Communication Council of Union of Chambers and Commodity Exchanges of Turkey (TOBB). Her recent research focuses on reputation management, public relations ethics, crisis management and issues management.

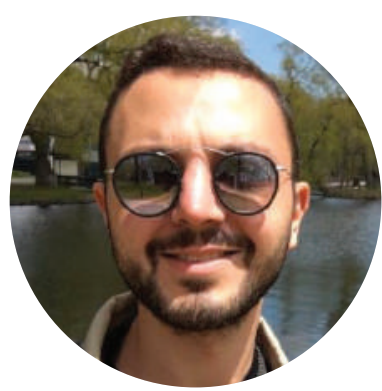

Vehbi Gorgulu ........

Vehbi Gorgulu, PhD, is an assistant professor at Public Relations Program, Faculty of Communication, Istanbul Bilgi University, where he teaches public relations theory, digital literacy and social media. He is also the coordinator of public relations student agency Publica İletişim, where he teaches public relations practice and coordinates student projects. Gorgulu received his $\mathrm{PhD}$ Degree in Media and Communications from Galatasaray University and published various books and articles on social media and society. His recent research focuses on intersections between sustainability, corporate communications and social media. 